ISSN 1678-3921

Journal homepage: www.embrapa.br/pab

For manuscript submission and journal contents, access: www.scielo.br/pab

\section{Performance and genetic variation in a provenance test of Araucaria cunninghamii}

\begin{abstract}
The objective of this work was to assess the genetic variability of Araucaria cunninghamii in a provenance test and to estimate the genetic gains in its wood production, based on different selection intensities. The trial was established in Luís Antônio, in the state of São Paulo, Brazil, using openpollinated seed from Queensland, Australia. The experimental design used was a randomized complete block with six replicates, and four plants per plot. Diameter at breast height (DBH), stem form, and survival were measured at 29 years after planting. Significant differences were detected among provenances. The coefficient of genotypic variation between provenances was high $(60 \%)$ for DBH and stem form. The mean values for DBH and stem form were $23.21 \mathrm{~cm}$ and 4.50, respectively. The provenances Langkelly Creek, Brooweena L.A., Yarraman, and St. Agnes showed the best performance for DBH, and Imbil Seed Orchard, Brooweena L.A, St. Agnes, St. John, and Yarraman, for stem form. Genetic gains ranged from 0.5 to $24.8 \%$ for DBH, and from 0.9 to $3.5 \%$ for stem form.
\end{abstract}

Index terms: conifer, genetic parameters, tree breeding.

\section{Desempenho e variação genética em teste de procedência de Araucaria cunninghamii}

Resumo - O objetivo deste trabalho foi avaliar a variabilidade genética de Araucaria cunninghamii, em teste de procedência, e estimar ganhos genéticos para a produção de sua madeira, com base em diferentes intensidades de seleção. O experimento foi estabelecido em Luís Antônio, no estado de São Paulo, Brasil, com sementes de polinização aberta coletadas em Queensland, Austrália. O delineamento experimental utilizado foi o de blocos ao acaso, com seis repetições e quatro plantas por parcela. $\mathrm{O}$ diâmetro à altura do peito (DBH), a forma do fuste e a sobrevivência foram medidos 29 anos após o plantio. Diferenças significativas foram detectadas entre as procedências. O coeficiente de variação genotípica foi alto $(60 \%)$ para DBH. Os valores médios de DBH e forma do fuste foram de $23,21 \mathrm{~cm}$ e 4,50, respectivamente. As procedências Langkelly Creek, Brooweena L.A., Yarraman e St. Agnes apresentaram melhor desempenho em DBH, e Imbil Seed Orchard, Brooweena L.A., St. Agnes, St. John e Yarraman, em forma do fuste. Os ganhos estimados com a seleção variaram de 0,5 a 24,8\%, para DBH, e de 0,9 a 3,5\%, para forma do fuste.

Termos para indexação: conífera, parâmetros genéticos, melhoramento florestal. 


\section{Introduction}

In Brazil, the importation of forest genetic resources from other countries, mainly Australia and North America, are essential for the maintenance of the forest-based production chain (Brockerhoff et al., 2013). The search for new or alternative forest species for timber production has intensified in recent years. Large-scale timber producers are now looking for tropical and subtropical species with as yet untapped potential (Nambiar, 2019). For instance, the Araucariaceae family includes more than 17 species that occur throughout Australia, one of which is Araucaria cunninghamii Aiton ex D. Don.

Recently, timber companies have shown interest in commercial exploitation of this species, as it shows silvicultural traits suitable for wood production, but it can also be used in the long-fiber pulp industry (Setiadi \& Fauzi, 2015). The new commercial interest in this species logging has stimulated the development of new production technologies. Recent studies have shown development in the physicochemical characterization of its wood (McGavin et al., 2019; Fitzgerald \& McGavin, 2020). The improvement of this species cultivation techniques has also been observed in different aspects (Sarmast et al., 2012; Lin et al., 2016; Matsabisa et al., 2019; Wang et al., 2020). In comparation to other more commercially valuable species such as loblolly pine and slash pine (Pinus taeda L. and Pinus elliottii, respectively), there has been less effort toward developing and deploying genetically improved and more productive individuals (Castillo et al., 2018). However, studies have determined that the genetic variation found in the Araucaria species is similar to that found in other southern pines, making them a suitable species for genetic breeding programs (Castillo et al., 2018). Thus, the study of germplasms of this species in Brazil may contribute to diversify forest plantations as a new species option for specific regions, as well as for the development of interspecific hybrids with other species of the same genus. Therefore, the characterization of provenance tests, as well as a selection of more productive individuals near planting sites is strategic for its use and conservation of germplasm.

Most of the genotypes used for wood production in South Africa (Congo) and Australia originated from Queensland, where the planting area of the species has reached 50,000 ha (Manson et al., 2013). In Australia, several provenances of Papua New Guinea (PNG) have been introduced in north and south Queensland in the past 20 years. Efforts to breed a hybrid between the most advanced genotype of south Queensland with the best genotypes from north Queensland and PNG provenances of the species showed promising results (Dieters et al., 2007). Genetic gains have been achieved in new north Queensland plantations only with the development of genetic resources studies. Clonal seed orchard composed of selected trees from a population of individuals from PNG and north Queensland and small stands of second-generation PNG and firstgeneration (F1) hybrid families are already well established in the region (Dieters et al., 2007).

In Brazil, it is necessary to verify if the introduced genotypes are enough to advance the species breeding program. The provenance test may be used at first for the development of interspecific hybrids and small plant establishments, in companies that are interested in diversifying their forests and have various product purposes. Therefore, the more productive individuals within several provenances should be selected (Sousa et al., 2018), as well as propagated either by seeds or clonally. These forest plantations may generate more gains for timber yield, improved cost-effectiveness, and increased plantation profitability (Nichols \& Vanclay, 2012).

The objective of this work was to assess the genetic variability in an $A$. cunninghamii provenance test and estimate genetic gains in wood production based on different selection intensities.

\section{Materials and Methods}

The provenance test was established with a seed mix from ten open-pollinated A. cunninghamii provenances from Queensland state, Australia (Table 1). Seed from each mother were mixed to represent their geographical origin and sent to the Instituto Florestal de São Paulo, in 1984, by the Forest Department of Brisbane, Australia (Sebbenn et al., 2005). The provenances Benarkin, St. Agnes, Brooweena L.A., St. John, Jimna, Bulburin, Clifford, and Langkelly Creek were collected from natural populations, while the provenance Imbil Seed Orchard is a seed orchard, and Yarraman is a commercial stand. The provenance test was planted in November 1985, at Luiz Antônio Experimental Station, in the municipality of Luiz 
Antônio $\left(21^{\circ} 40^{\prime} \mathrm{S}, 47^{\circ} 49^{\prime} \mathrm{W}\right.$, at $550 \mathrm{~m}$ altitude), in the state of São Paulo, Brazil. The climate of the site is tropical (Cwa), according to the Köppen-Geiger's classification, with mean annual temperatures at $22.7^{\circ} \mathrm{C}$ in the hottest month and $17.2^{\circ} \mathrm{C}$ in the coldest month, dry winters, and $1,280 \mathrm{~mm}$ average annual rainfall (Sebbenn et al., 2005). The relief of the site is flat with a slope of about $5 \%$, and the soil is classified as Latossolo Vermelho, according to the Brazilian Soil Classification System (Santos et al., 2018), i.e., an Oxisol (Soil Survey Staff, 2014). The experiment was established using a randomized complete block design, with ten treatments (provenances), six replicates (blocks), and four plants spaced at $3 \times 2 \mathrm{~m}$ per plot. The evaluated traits were: diameter at breast height (DBH); survival; and stem form. The trait stem form was assessed visually and classified according to a pre-established scale, defined by Guerra et al. (2009) as: 1, full tortuosity of the stem; 2, accentuated tortuosity below $1.30 \mathrm{~m} ; 3$, accentuated tortuosity above $1.30 \mathrm{~m}$; 4, minimal tortuosity throughout; and 5 , no tortuosity.

The estimates of the genetic parameters were obtained by the maximum likelihood/best unbiased linear prediction (REML/BLUP) method, using the Selegen-REML/BLUP software (Resende, 2016). The traits were analyzed using a univariate additive mixed linear model, based on the statistical model: $\mathrm{y}=\mathrm{Xr}+\mathrm{Zg}+\mathrm{Wp}+\mathrm{e}$; where: $\mathrm{y}$ is the data vector; $\mathrm{r}$ is the vector of the replicate effects (assumed to be fixed) added to the general mean; $g$ is the vector of genotypic effects of provenances (assumed to be random); $p$ is the vector of plot effects; and e is the vector of errors or residuals (random). Capital letters represent the incidence matrices for these effects. An analysis of deviance was performed for the random effects. The random effects of the mixed model with unbalanced data were tested using the likelihood ratio test (LRT). The estimated variance components were: among provenance variance $\left(\sigma_{\mathrm{p}}^{2}\right)$, plot variance $\left(\sigma_{\mathrm{c}}^{2}\right)$, and residual variance $\left(\sigma_{\mathrm{e}}^{2}\right)$. From the variance components, the parameters were estimated as follows.

The individual heritability in the broad sense, which reflects the total genotypic effects of the provenances:

$$
H_{p}^{2}=\frac{\sigma_{p}^{2}}{\sigma_{p}^{2}+\sigma_{c}^{2}+\sigma_{e}^{2}}
$$

The provenance mean heritability:

$$
\mathrm{H}_{\mathrm{pm}}^{2}=\frac{\left(\frac{1}{4}\right) \sigma_{\mathrm{p}}^{2}}{\left(\frac{1}{4}\right) \sigma_{\mathrm{p}}^{2}+\frac{\sigma_{\mathrm{c}}^{2}}{\mathrm{r}}+\frac{\left(0.75 \sigma_{\mathrm{p}}^{2}+\sigma_{\mathrm{e}}^{2}\right)}{\mathrm{nr}}}
$$

in which: $\mathrm{n}$ is the number of plants per plot; and $\mathrm{r}$ is the number of replicates (blocks).

Selection accuracy:

$$
\mathrm{r}_{\mathrm{aaa}}=\sqrt{\mathrm{h}_{\mathrm{pm}}^{2}}
$$

Coefficient of determination of the plot effects:

\begin{tabular}{|c|c|c|c|c|c|c|}
\hline Provenance & $\begin{array}{l}\text { Number of seed } \\
\text { trees }\end{array}$ & Latitude S & Longitude $\mathrm{E}$ & $\begin{array}{l}\text { Altitude } \\
(\mathrm{m})\end{array}$ & $\begin{array}{c}\text { Mean annual } \\
\text { precipitation }(\mathrm{mm})\end{array}$ & $\begin{array}{c}\begin{array}{c}\text { Survival rate } \\
(\%)\end{array} \\
\end{array}$ \\
\hline Benarkin & 10 & $26^{\circ} 55^{\prime}$ & $152^{\circ} 09^{\prime}$ & 440 & 992 & \\
\hline St. Agnes & 42 & $25^{\circ} 20^{\prime}$ & $151^{\circ} 50^{\prime}$ & 280 & 930 & \\
\hline Brooweena L.A. & 20 & $25^{\circ} 32^{\prime}$ & $150^{\circ} 13^{\prime}$ & 122 & 1056 & \\
\hline St. John & 20 & $27^{\circ} 14^{\prime}$ & $152^{\circ} 40^{\prime}$ & 400 & 1200 & \\
\hline Jimna & 20 & $26^{\circ} 42^{\prime}$ & $152^{\circ} 20^{\prime}$ & 600 & 817 & \\
\hline Bulburin & - & $24^{\circ} 25^{\prime}$ & $151^{\circ} 30^{\prime}$ & 540 & 1447 & \\
\hline Clifford & $10 / 20$ & $24^{\circ} 40^{\prime}$ & $151^{\circ} 00^{\prime}$ & 810 & 1200 & \\
\hline Imbil Seed Orchard & 20 & $26^{\circ} 27^{\prime}$ & $152^{\circ} 40^{\prime}$ & 105 & 1200 & \\
\hline Yarraman & 20 & $26^{\circ} 51^{\prime}$ & $152^{\circ} 10^{\prime}$ & 435 & 1000 & \\
\hline Langkelly Creek & 20 & $13^{\circ} 54^{\prime}$ & $143^{\circ} 15^{\prime}$ & 500 & 1200 & \\
\hline Total & & & & & & 79 \\
\hline
\end{tabular}

Table 1. Provenance name, number of seed trees from which seed were collected, latitude and longitude, altitude, and mean annual precipitation of the original site of Araucaria cunninghamii provenances in Australia. 


$$
\mathrm{C}_{\mathrm{c}}^{2}=\frac{\sigma_{\mathrm{c}}^{2}}{\sigma_{\mathrm{p}}^{2}+\sigma_{\mathrm{c}}^{2}+\sigma_{\mathrm{e}}^{2}}
$$

In order to select superior genotypes for breeding programs and commercial plantations, two selection strategies were simulated from the ranking of the additive genetic value: the first selection was based on individual ranking, with nine selection intensities $(5,7.5,10,12.5,15,17.5,20,40,50 \%)$; and the second selection was carried out within each provenance with two selection intensities (25 and 50\%; 1 and 2 individuals within the provenance, respectively). The selection was carried out for $\mathrm{DBH}$ and stem form. The genetic gain was estimated as a percentage: $\mathrm{G}_{\mathrm{S}}=\left[\left(\sum \mathrm{a}+\mu\right) / \mu\right] \times 100$, in which: $\mathrm{a}+\mu$ corresponds to the additive genetic value of the selected individual, and $\mu$ corresponds to the overall mean of the experiment for the $\mathrm{DBH}$ and stem form traits.

\section{Results and Discussion}

Out the 240 planted individuals, $78 \%$ survived at 29 years after planting (Table 1). This result indicates a good adaptation to the site, considering that it is an exotic species that was not previously domesticated through selection in breeding programs for the study area (Kabrick et al., 2015).

The provenance effect was significant for $\mathrm{DBH}$ based on the analysis of deviance (Table 2). The population showed a considerable phenotypic variation among individuals for both tested traits. The values observed for the coefficient of phenotypic variation suggest the potential use of the trial for improvement programs. This variation is a reflection of the natural variation in populations of the species and indicates that the seed sampling was effective in capturing part of the total variance in natural populations (Inza et al., 2018). These values were higher than those observed for growth traits of $A$. angustifolia provenances and progenies (10.2\%), observed by Silva et al. (2018) for the same traits of the present study. This shows that A. cunninghamii can have a higher variability to be exploited than some populations of native species. The coefficient of determination of the plot effects was low for the two traits $(<0.1)$, showing that there was no environmental influence within blocks and plots.

The mean provenance heritability was high for $\mathrm{DBH}$ and stem form. This resulted in a high selection accuracy for $\mathrm{DBH}$, and in moderate accuracy for stem form, which indicates that field measurements are highly reliable. Accuracy values up to 0.40 are considered low, those from 0.50 to 0.70 , moderate, and, those above 0.80 , high (Resende, 2016). The result for is unusual as several studies have demonstrated low heritability in A. cunninghamii progeny tests for quantitative growth traits, particularly $\mathrm{DBH}$ and height (Scott et al., 2005). The coefficient of broad sense heritability of the provenance was low for both DBH and stem form. Previous studies on the species reported heritability values ranging from 0.11 to 0.48 for $\mathrm{DBH}$ and from 0.13 to 0.53 for stem form, in progeny tests at 4 to 16 years of age (Eisemann et al., 1990; Harding \& Woolaston, 1991; Dieters et al., 2007; Setiadi, 2010; Setiadi \& Susanto, 2012; Setiadi \& Fauzi, 2015). For $A$. angustifolia, low to high individual heritability coefficients for DBH were observed in provenance and progeny tests ranging from 0.03 to 0.95 (Sebbenn et al., 2004; Silva et al., 2015, 2018), while a trend of

Table 2. Analysis of deviance and estimates of the genetic parameters for diameter at breast height (DBH) and stem form in Araucaria cunninghamii provenances at 29 years of age.

\begin{tabular}{lcc}
\hline Parameter & DBH $(\mathrm{cm})$ & Stem form \\
\hline Likelihood ratio test (LRT) & $10.15^{* *}$ & 0.13 \\
Phenotypic mean $(\mu \pm \mathrm{SD})$ & $23.21 \pm 8.53$ & $4.50 \pm 0.75$ \\
Coefficient of variation $(\mathrm{CV}, \%)$ & 36.5 & 16.6 \\
Minimum/maximum values & $7.96 / 48.0$ & $1.07 / 5.0$ \\
Coefficient of determination of plot effects $\left(\mathrm{C}_{\mathrm{p}}^{2}\right)$ & 0.09 & 0.01 \\
Broad-sense individual heritability $\left(\mathrm{H}_{\mathrm{p}}^{2} \pm \mathrm{SD}\right)$ & $0.09 \pm 0.06$ & $0.04 \pm 0.0)$ \\
Provenance mean heritability $\left(\mathrm{H}_{\mathrm{pm}}^{2}\right)$ & 0.65 & 0.52 \\
Selection accuracy $\left(\mathrm{r}_{\mathrm{a}}\right)$ & 0.80 & 0.72 \\
\hline
\end{tabular}

LRT was based on chi-square tests with 1 degree of freedom; SD is the standard deviation. **Significant at $1 \%$ probability (LTR $>6.63)$. 
increasing heritability over time was also observed for A. angustifolia provenances (Silva et al., 2020). This highlights the importance of establishing trials using a representative sampling process. The results indicate that the genotypes under study have a promising capacity for the use of their genetic heritage in the breeding process.

The provenances Langkelly Creek, Brooweena L.A., Yarraman, and St. Agnes resulted in the greatest genetic gains for DBH (Table 3), showing that significant genetic gains can be achieved with the selection of these provenances. In contrast, expected genetic gains would be relatively inferior with the selection of the provenances Imbil Seed Orchard, Clifford, St. John, Benarkin, and Bulburin. Genetic gains were estimated with basis on the selection of the best genotype performance for $\mathrm{DBH}$ and stem form, reaching values ranging from 0.5 to $24.8 \%$ and 0.9 to $3.5 \%$, respectively (Table 4 ).

Sebbenn et al. (2004) evaluated a 30-year-old $A$. angustifolia provenance and progeny test in Itapeva, in the state of São Paulo, Brazil, and reported

Table 3. Ranking of provenances based on genotypic values for diameter at breast height (DBH) and stem form (SF) of Araucaria cunninghamii at 29 years of age.

\begin{tabular}{cccccc}
\hline Rank & \multicolumn{2}{c}{ DBH } & & \multicolumn{2}{c}{ Stem form } \\
\cline { 2 - 3 } \cline { 5 - 6 } & Provenance & Genotypic value & Provenance & Genotypic values \\
\hline 1 & Langkelly Creek & 3.898 & Imbil Seed Orchard & 0.130 \\
3 & Brooweena L.A. & 2.699 & Brooweena L.A. & 0.118 \\
4 & Yarraman & 0.764 & St. Agnes & 0.108 \\
5 & St. Agnes & 0.048 & St. John & 0.058 \\
6 & Imbil Seed Orchard & -0.661 & Yarraman & -0.052 \\
7 & Clifford & -1.832 & Jimna & -0.027 \\
8 & St. John & -3.804 & Benarkin & -0.045 \\
9 & Benarkin & -5.491 & Bulburin & -0.075 \\
10 & Bulburin & -8.727 & Clifford & -0.159 \\
\hline
\end{tabular}

Table 4. Expected genetic gains $\left(\mathrm{G}_{\mathrm{s}}\right)$ for different levels of selection intensity based on genotypic values for diameter at breast height (DBH) and stem form, in Araucaria cunninghamii provenances at 29 years of age.

\begin{tabular}{|c|c|c|c|c|c|c|}
\hline \multirow{2}{*}{$\begin{array}{l}\text { Selection } \\
\text { intensity }\end{array}$} & Diameter at breast height (DBH) & \multirow[t]{2}{*}{$\mathrm{n}_{\mathrm{s}}$} & \multirow{2}{*}{$\begin{array}{l}\mathrm{G}_{\mathrm{s}} \\
(\%)\end{array}$} & Stem form & \multirow[t]{2}{*}{$\mathrm{n}_{\mathrm{s}}$} & \multirow{2}{*}{$\begin{array}{l}\mathrm{G}_{\mathrm{s}} \\
(\%\end{array}$} \\
\hline & Selected provenance & & & Selected provenance & & \\
\hline $\mathrm{G}_{\mathrm{SI}_{\mathrm{I}}}(5 \%)$ & 10 & 10 & 24.8 & $2,3,8$ & 10 & 3.5 \\
\hline $\mathrm{G}_{\mathrm{S}_{\mathrm{I}}}(7.5 \%)$ & 10 & 15 & 24.3 & $2,3,8$ & 15 & 3.4 \\
\hline $\mathrm{G}_{\mathrm{S}_{\mathrm{I}}}(10 \%)$ & 10 & 19 & 24.1 & $2,3,8$ & 19 & 3.3 \\
\hline $\mathrm{G}_{\mathrm{S}_{\mathrm{I}}}(12.5 \%)$ & $3,9,10$ & 23 & 23.1 & $2,3,8$ & 23 & 3.2 \\
\hline $\mathrm{G}_{\mathrm{SI}_{\mathrm{I}}}(15 \%)$ & $2,3,9,10$ & 28 & 23.9 & $2,3,8$ & 28 & 3.2 \\
\hline $\mathrm{G}_{\mathrm{S}_{\mathrm{I}}}(17.5 \%)$ & $2,3,8,9,10$ & 33 & 22.1 & $2,3,8$ & 33 & 3.1 \\
\hline $\mathrm{G}_{\mathrm{SI}_{\mathrm{I}}}(20 \%)$ & $2,3,4,7,8,9,10$ & 38 & 20.1 & $2,3,8$ & 38 & 3.0 \\
\hline $\mathrm{G}_{\mathrm{S}_{\mathrm{I}}}(40 \%)$ & $2,3,4,6,7,89,10$ & 75 & 3.35 & $2,3,4,8,9$ & 75 & 2.7 \\
\hline $\mathrm{G}_{\mathrm{SI}_{\mathrm{I}}}(50 \%)$ & $2,3,4,6,7,8,9,10$ & 94 & 2.7 & $1,2,3,4,5,8,9$ & 94 & 2.5 \\
\hline $\mathrm{G}_{\mathrm{SID}_{\mathrm{ID}}(25 \%)}$ & $1,2,3,4,6,7,8,9,10$ & 60 & 2.2 & $1,2,3,4,6,7,8,9,10$ & 60 & 1.3 \\
\hline $\mathrm{G}_{\mathrm{SID}_{\mathrm{ID}}}(50 \%)$ & $1,2,3,4,6,7,8,9,10$ & 120 & 0.0 & $1,2,3,4,6,7,8,9,10$ & 120 & 0.9 \\
\hline
\end{tabular}

$\mathrm{n}_{\mathrm{s}}$ is the number of selected individuals; $\mathrm{G}_{\mathrm{s}}(\%)$ is the expected genetic gain with individual selection; $\mathrm{G}_{\mathrm{s}}(\%)$ is the expected genetic gain with provenance selection. Provenance: 1, Benarkin; 2, St. Agnes; 3, Brooweena L.A.; 4, St. John; 5, Jimna; 6, Bulburin; 7, Clifford; 8, Imbil Seed Orchard; 9 , Yarraman; 10, Langkelly Creek. 
DBH of $20.47 \mathrm{~cm}(0.71 \mathrm{~cm}$ growth per year). This suggests that, in Brazil, A. cunninghamii can show $\mathrm{DBH}$ growth of $23.21 \mathrm{~cm}$ (or $0.8 \mathrm{~cm}$ per year), that is $11.2 \%$ higher than the native $A$. angustifolia. This outcome also proves to be true at younger ages; the mean $6.59 \mathrm{~cm} \mathrm{DBH}$ at four years of age was reported for A. angustifolia (Silva et al., 2018), while DBH values for $A$. cunninghamii progenies at 10 years of age up to $20.59 \mathrm{~cm}$ were reported in a test installed in Yogyakarta di Bondowoso (Setiadi \& Fauzi, 2015). Meanwhile, Dieters et al. (2003) shows studies that found height values for A. cunninghamii close to 17 $\mathrm{m}$ in tests of progenies at 15 and 16 years of age, respectively. These results show that, depending on the growth stage and environmental conditions, the introduced tree species may have a similar, or even higher performance than A. angustifolia.

The stem form 4.5 indicates that, on average, trees showed low levels of tortuosity throughout the stem, or an adequate stem form for timber production (Table 1). For sawn wood, this is a very important trait to assess. When the tree shows tortuosity in the stem, the loss of lumber in the sawmill can reach $50 \%$ (Lima et al., 2020). Furthermore, this species shows a higher stem form compared to other native and exotic species planted in Brazil. Values lower than three were reported for provenances and progenies of Handroanthus vellosoi (Batista et al., 2012), a provenance of Myracrodruon urundeuva (Freitas et al., 2006), and Dipteryx alata progenies (Canuto et al., 2015).

As to growth traits, the results show genetic variation between provenances (Table 2). Setiadi (2010) also noted significant differences for height and DBH traits between A. cunninghamii progenies. Similar studies with $A$. angustifolia have detected significant differences for phenotypic traits at progeny (Duarte et al., 2012; Topanotti et al., 2019) and provenance levels (Sebbenn et al., 2004; Silva et al., 2018, 2020). These findings show that the Araucaria species have high genetic variability, and that the introduced species can be used as much as the native one. Thus, it is possible to make use of both species in a complementary way, or develop a hybrid using the more productive individuals from two species. Furthermore, a previous analysis of the studied trial herein reported positive genetic correlation between $\mathrm{DBH}$ and height, which can be exploited through the selection process (Sebbenn et al., 2005). However, for stem form, significant differences between provenances were not observed. Therefore, there is a low chance of success for selection based on this trait, as the provenance has a large number of individuals with the maximum score.

The provenances of Langkelly Creek, Yarraman, Brooweena L.A., and St. Agnes showed the best results for selection based on DBH performance, considering all levels of selection intensity. For stem form, the provenances with the best performance were Imbil Seed Orchard Brooweena L.A, St. Agnes, St. John, and Yarraman. For a genetic breeding program targeting both traits, the selection of individuals from Brooweena L.A., Yarraman, and St. Agnes provenances would be interesting even though stem form does not show significant difference among provenances. The selection and use of genotypes of the best performing provenances will be determinant in increasing commercial plantation productivity in the studied region (Sousa et al., 2020). However, for breeding programs that also focus on the conservation of genetic resources, all provenances should be represented in new selected populations, in order to prevent the loss of alleles from the original population (Sousa et al., 2020). At 20 years of age, we observed $23 \%$ genetic divergence among provenances in the present study, indicating that most diversity was distributed within provenances and not among them (Sebbenn et al., 2005).

Setiadi \& Fauzi (2015) studied A. cunninghamii and reported genetic gains of 0.1 and $0.07 \%$ for tree heights at five and ten years of age, respectively, and 0.53 and $1.01 \%$ for DBH. Dean et al. (1988) estimated genetic gains from selection of $A$. cunninghamii in its native region (southeast Queensland) and found lower expected gains than those reported in the present study. However, the authors used a selection index that was not recommended in the current study. As the genetic variation for stem form was low in the studied population, and practically all provenances performed well for this trait, selection should focus on $\mathrm{DBH}$. The genetic gain is determined by heritability, selection intensity, and the phenotypic variation of the trait (Sudrajat et al., 2016). Thus, traits that show low heritability and phenotypic variability, as observed for stem form, usually do not respond well to low- or moderate-intensity selection processes. 
For $A$. angustifolia, Silva et al. (2018) recommend a strategy of lower intensity selection (38\%) based on $\mathrm{DBH}$, in order to retain high levels of genetic diversity and effective population size. In the current study, low-intensity selection should be adopted to avoid excessive loss of genetic variability, in the formation of the subsequent generations of breeding population, as this trial represents one of the main sources of genotypes for further development of $A$. cunninghamii breeding programs in Brazil.

\section{Conclusions}

1. The provenance test shows a high genetic variability for the growth traits.

2. The use of individuals with better growth performance within the provenances Brooweena L.A., Yarraman, and St. Agnes is recommended for the development of breeding programs and use in commercial pilot planting, in regions with similar environmental conditions to the tested area.

\section{Acknowledgments}

To Conselho Nacional de Desenvolvimento Científico e Tecnológico (CNPq), for financial support; and to Instituto Florestal de São Paulo, for initiating the research project and conducting the experiment.

\section{References}

BATISTA, C.M.; FREITAS, M.L.M.; MORAES, M.A. de; ZANATTO, A.C.S.; SANTOS, P.C. dos; ZANATA, M.; MORAES, M.L.T. de; SEBBENN, A.M. Estimativas de parâmetros genéticos e a variabilidade em procedências e progênies de Handroanthus vellosoi. Pesquisa Florestal Brasileira, v.32, p.269-276, 2012. DOI: https://doi.org/10.4336/2012.pfb.32.71.269.

BROCKERHOFF, E.G.; JACTEL, H.; PARROTTA, J.A.; FERRAZ, S.F.B. Role of eucalypt and other planted forests in biodiversity conservation and the provision of biodiversity-related ecosystem services. Forest Ecology and Management, v.301, p.43-50, 2013. DOI: https://doi.org/10.1016/j.foreco.2012.09.018.

CANUTO, D.S. de O.; ZARUMA, D.U.G.; MORAES, M.A. de; SILVA, A.M. da; MORAES, M.L.T. de; FREITAS, M.L.M. Caracterização genética de um teste de progênies de Dipteryx alata Vog. provenientes de remanescente florestal da Estação Ecológica de Paulo de Faria, SP, Brasil. Hoehnea, v.42, p.641648, 2015. DOI: https://doi.org/10.1590/2236-8906-13/RAD/2015.

CASTILlO, A.C.; GOLDFARB, B.; JOHNSEN, K.H.; ROBERDS, J.H.; NELSON, C.D. Genetic variation in water-use efficiency (WUE) and growth in mature longleaf pine. Forests, v.9, art.727, 2018. DOI: https://doi.org/10.3390/f9110727.

DEAN, C.A.; NIKLES, D.G.; HARDING, K.J. Estimates of genetic parameters and gains expected from selection in hoop pine in south-east Queensland. Silvae Genetica, v.37, p.243-247, 1988.

DIETERS, M.J.; NIKLES, D.G.; JOHNSON, M.J. Genetic improvement and conservation: a case study of Araucaria cunninghamii. In: INTERNATIONAL CONFERENCE, 2002, Yogyakarta. Advances in genetic improvement of tropical tree species: proceedings. Yogyakarta: Centre for Forest Biotechnology and Tree Improvement, 2003. p.89-98. Editors: A. Rimbawanto, and M. Susanto.

DIETERS, M.J.; NIKLES, D.G.; KEYS, M.G. Achievements in forest tree improvement in Australia and New Zealand 6: genetic improvement and conservation of Araucaria cunninghamii in Queensland. Australian Forestry, v.70, p.75-85, 2007. DOI: https://doi.org/10.1080/00049158.2007.10675006.

DUARTE, R.I.; SILVA, F.A.L.S. da; SCHULTZ, J.; SILVA, J.Z. da; REIS, M.S. dos. Características de desenvolvimento inicial em teste de progênie de uma população de araucária na Flona de Três Barras-SC. Biodiversidade Brasileira, v.2, p.114-123, 2012.

EISEMANN, R.L.; HARDING, K.J.; ECCLES, D.B. Genetic parameters and predicted selection responses for growth and wood properties in a population of Araucaria cunninghamii. Silvae Genetica, v.39, p.206-216, 1990.

FITZGERALD, C.J.; MCGAVIN, R.J. Blended species plywood (white cypress pine and hoop pine): Effect of veneer thickness on susceptibility to attack by the subterranean termite Coptotermes acinaciformis. BioResources, v.15, p.4655-4671, 2020. DOI: https://doi.org/10.15376/biores.15.3.4655-4671.

FREITAS, M.L.M.; AUKAR, A.P. de A.; SEBBENN, A.M.; MORAES, M.L.T. de; LEMOS, E.G.M. Variação genética em progênies de myracrodruon urundeuva F.F. \& M.F. Allemão em três sistemas de cultivo. Revista Árvore, v.30, p.319-329, 2006. DOI: https://doi.org/10.1590/S0100-67622006000300001.

GUERRA, C.R.S.B.; MORAES, M.L.T. de; SILVA, C.L.S.P. da; CANUTO, D.S. de O.; ANDRADE, J.A. da C.; FREITAS, M.L.M.; SEBBENN, A.M. Estratégias de seleção dentro de progênies em duas populações de Myracrodruon urundeuva Fr. All. Scientia Forestalis, v.37, p.79-87, 2009.

HARDING, K.J.; WOOLASTON, R.R. Genetic parameters for wood and growth properties in Araucaria cunninghamii. Silvae Genetica, v.40, p.232-237, 1991

INZA, M.V.; AGUIRRE, N.C.; TORALES, S.L.; PAHR, N.M.; FASSOLA, H.E.; FORNES, L.F.; ZELENER, N. Genetic variability of Araucaria angustifolia in the Argentinean Parana Forest and implications for management and conservation. Trees, v.32, p.1135-1146, 2018. DOI: https://doi.org/10.1007/s00468-0181701-4.

KABRICK, J.M.; KNAPP, B.O.; DEY, D.C.; LARSEN, D.R. Effect of initial seedling size, understory competition, and overstory density on the survival and growth of Pinus echinata seedlings underplanted in hardwood forests for restoration. New 
Forests, v.46, p.897-918, 2015. DOI: https://doi.org/10.1007/ s11056-015-9487-3.

LIMA, R.B.; FERREIRA, R.L.C.; SILVA, J.A.A. da; GUEDES, M.C.; SILVA, D.A.S. da; OLIVEIRA, C.P. de; RABELO, F.G.; SILVA, L.F. da C. Effect of species and log diameter on the volumetric yield of lumber in northern Brazilian Amazonia: preliminary results. Journal of Sustainable Forestry, v.39, p.283-299, 2020. DOI: https://doi.org/10.1080/10549811.2019.163 6661.

LIN, C.J.; HUANG, Y.H.; HUANG, G.S.; WU, M.L.; YANG, T.H. Detection of termite damage in hoop pine (Araucaria cunninghamii) trees using nondestructive evaluation techniques. Journal of Tropical Forest Science, v.28, p.79-87, 2016.

MANSON, D.G.; SCHMIDT, S.; BRISTOW, M.; ERSKINE, P.D.; VANCLAY, J.K. Species-site matching in mixed species plantations of native trees in tropical Australia. Agroforestry Systems, v.87, p.233-250, 2013. DOI: https://doi.org/10.1007/ s10457-012-9538-0.

MATSABISA, M.G.; CHUKWUMA, C.I.; IBEJI, C.U.; CHAUDHARY, S.K. Stem bark exudate (resin) of Araucaria cunninghamii Aiton ex D. Don (hoop pine) abates glycation, $\alpha$-glucosidase and DPP-IV activity and modulates glucose utilization in Chang liver cells and 3T3-L1 adipocytes. South African Journal of Botany, v.121, p.193-199, 2019. DOI: https://doi.org/10.1016/j.sajb.2018.11.004.

MCGAVIN, R.L.; NGUYEN, H.H.; GILBERT, B.P.; DAKIN, T.; FAIRCLOTH, A. A comparative study on the mechanical properties of laminated veneer lumber (LVL) produced from blending various wood veneers. BioResources, v.14, p.90649081, 2019.

NAMBIAR, E.K.S. Tamm Review: Re-imagining forestry and wood business: pathways to rural development, poverty alleviation and climate change mitigation in the tropics. Forest Ecology and Management, v.448, p.160-173, 2019. DOI: https://doi.org/10.1016/j.foreco.2019.06.014.

NICHOLS, J.D.; VANCLAY, J.K. Domestication of native tree species for timber plantations: key insights for tropical island nations. International Forestry Review, v.14, p.402-413, 2012. DOI: https://doi.org/10.1505/146554812804715892.

RESENDE, M.D.V. Software Selegen-REML/BLUP: a useful tool for plant breeding. Crop Breeding and Applied Biotechnology, v.16, p.330-339, 2016. DOI: https://doi.org/10.1590/1984$70332016 \mathrm{v} 16 \mathrm{n} 4 \mathrm{a} 49$.

SANTOS, H.G. dos; JACOMINE, P.K.T.; ANJOS, L.H.C. dos; OLIVEIRA, V.Á. de; LUMBRERAS, J.F.; COELHO, M.R.; ALMEIDA, J.A. de; ARAÚJO FILHO, J.C. de; OLIVEIRA, J.B. de; CUNHA, T.J.F. Sistema brasileiro de classificação de solos. 5.ed. rev. e ampl. Brasília: Embrapa, 2018. 356p.

SARMAST, M.K.; SALEHI, H.; KHOSH-KHUI, M. Micropropagation of Araucaria excelsa R. Br. var. glauca Carrière from orthotropic stem explants. Physiology and Molecular Biology of Plants, v.18, p.265-271, 2012. DOI: https://oi.org/10.1007/s12298-012-0115-9.
SCOTT, L.J.; SHEPHERD, M.J.; NIKLES, D.G.; HENRY, R.J. Low efficiency of pseudotestcross mapping design was consistent with limited genetic diversity and low heterozygosity in hoop pine (Araucaria cunninghamii, Araucariaceae). Tree Genetics \& Genomes, v.1, p.124-134, 2005. DOI: https://doi.org/10.1007/ s11295-005-0022-0.

SEBBENN, A.M.; PONTINHA, A. de A.S.; FREITAS, S.A. de; FREITAS, J.A. de. Variação genética em cinco procedências de Araucaria angustifolia (Bert.) O. Ktze. no sul do Estado de São Paulo. Revista do Instituto Florestal, v.16, p.91-99, 2004.

SEBBENN, A.M.; ZANATTO, A.C.S.; FREITAS, M.L.M.; SATO, A.S.; ETTORI, L. de C. Genetic variation in Araucaria cunninghamii provenances in Luiz Antonio-SP, Brazil. Crop Breeding and Applied Biotechnology, v.5, p.435-442, 2005. DOI: https://doi.org/10.12702/1984-7033.V05N04A09.

SETIADI, D. Keragaman Genetik Uji Provenas Dan Uji Keturunan Araucaria Cunninghamii Pada Umur 18 Bulan Di Bondowoso, Jawa Timur. Jurnal Pemuliaan Tanaman Hutan, v.4, p.1-8, 2010. DOI: https://doi.org/10.20886/jpth.2010.4.1.1-8.

SETIADI, D.; FAUZI, M.A. Parameter genetik pada kombinasi uji provenan dan uji keturunan Araucaria cunninghamii asal Manokwari (Papua) di Bondowoso, Jawa Timur. Jurnal Penelitian Kehutanan Wallacea, v.4, p.129-136, 2015. DOI: https://doi.org/10.18330/jwallacea.2015.vol4iss2pp129-136.

SETIADI, D.; SUSANTO, M. Variasi genetik pada kombinasi uji provenans dan uji keturunan Araucaria cunninghamii di Bondowoso-Jawa Timur. Jurnal Pemuliaan Tanaman Hutan, v.6, p.157-166, 2012. DOI: https://doi.org/10.20886/ jpth.2012.6.3.157-166.

SILVA, E.C.B. da; KUBOTA, T.Y.K.; MORAES, M.L.T. de; SEBBENN, A.M. Coeficientes de herdabiblidade e de parentesco em um fragmento florestal de Araucaria angustifolia (Bertol.) Kuntze utilizando marcadores genéticos. Scientia Forestalis, v.43, p.147-153, 2015.

SILVA, J.R. da; SANTOS, W. dos; MORAES M.L.T. de; SHIMIZU, J.Y.; SOUSA, V.A. de; AGUIAR, A.V. de. Seleção de procedências e progênies de Araucaria angustifolia (Bert.) O. Kuntze para produção de madeira e pinhão. Scientia Forestalis, v.46, p.519-531, 2018. DOI: https://doi.org/10.18671/scifor. v46n120.01.

SILVA, P.I.T.; SILVA-JUNIOR, O.B.; RESENDE, L.V.; SOUSA, V.A.; AGUIAR, A.V.; GRATTAPAGLIA, D. A 3K Axiom SNP array from a transcriptome-wide SNP resource sheds new light on the genetic diversity and structure of the iconic subtropical conifer tree Araucaria angustifolia (Bert.) Kuntze. PLoS One, v.15, e0230404, 2020. DOI: https://doi.org/10.1371/journal. pone.0230404.

SOIL SURVEY STAFF. Keys to soil taxonomy. $12^{\text {th }}$ ed. Washington: USDA, 2014. 360p.

SOUSA, V.A. de; KALIL FILHO, A.N.; MARTINS, E.G.; SHIMIZU, J.Y.; ALBERTIN, F. Gene diversity in Grevillea populations introduced in Brazil and its implication on management of genetic resources. Revista Árvore, v.42, e420205, 2018. DOI: https://doi.org/10.1590/1806-90882018000200005. 
SOUSA, V.A.; REEVES, P.A.; REILlEY, A.; AGUIAR, A.V. de; STEFENON, V.M.; RICHARDS, C.M. Genetic diversity and biogeographic determinants of population structure in Araucaria angustifolia (Bert.) O. Ktze. Conservation Genetics, v.21, p.217229, 2020. DOI: https://doi.org/10.1007/s10592-019-01242-9.

SUDRAJAT, D.J.; NURHASYBI, N.; SIREGAR, I.Z.; SIREGAR, U.J.; MANSUR, I.; KHUMAIDA, N. Intraspecific variation on early growth of Neolamarckia cadamba Miq. in provenanceprogeny tests in West Java Province, Indonesia. Biotropia: The Southeast Asian Journal of Tropical Biology, v.23, p.10-20, 2016. DOI: https://doi.org/10.11598/btb.2016.23.1.439.
TOPANOTTI, L.R.; GERBER, D.; STOLARSKI, O.C.; TRENTIN, B.E.; PERTILLE, C.T.; SCHORR, L.P.B.; GORESTEIN, M.R.; NICOLETTI, M.F.; BECHARA, F.C. Initial growth performance of valuable timber species in southern Brazil: Araucaria angustifolia, Balfourodendron riedelianum, and Parapiptadenia rigida. Revista Árvore, v.43, e430404, 2019. DOI: https://doi.org/10.1590/1806-90882019000400004.

WANG, D.; BLUMFIELD, T.J.; XU, Z. Long-term impacts of soil compaction and cultivation on soil carbon and nitrogen pools, foliar $\delta 13 \mathrm{C}$ and $\delta 15 \mathrm{~N}$ as well as tree growth in a hoop pine plantation of subtropical Australia. Journal of Soils and Sediments, v.20, p.2829-2842, 2020. DOI: https://doi.org/10.1007/ s11368-020-02654-8. 